\title{
Vitamin D Metabolism in Breast-Fed Infants and their Mothers
}

\author{
T. HOOGENBOEZEM, H. J. DEGENHART, S. M. P. F. DE MUINCK KEIZER-SCHRAMA, \\ R. BOUILLON, W. F. A. GROSE, W. H. L. HACKENG, AND H. K. A. VISSER \\ Department of Paediatrics, Erasmus University and University Hospital TT. H., H. J. D., S. M. P. F. D.M. K. S., \\ H. K. A. V.J and Department of Clinical Chemistry [W. F. A. G.J. Sophia Children's Hospital, Gordelweg 160, \\ 3038 GE Rotterdam, The Netherlands, Department of Clinical Chemistry [W. H. L. H.], Bergwegziekenhuis, \\ Rotterdam. The Netherlands, and Department of Experimental Medicine and Endocrinology [R. B.],
}

Gasthuisberg, Leuven, Belgium

\begin{abstract}
The aim of this longitudinal study was to examine vitamin $D$ metabolism in exclusively breast-fed infants. The four common vitamin $D$ metabolites-25hydroxyvitamin D (25OHD), 1,25-dihydroxyvitamin D $\left[1,25(\mathrm{OH})_{2} \mathrm{D}\right], 24,25$-dihydroxyvitamin $\mathrm{D}\left[24,25(\mathrm{OH})_{2} \mathrm{D}\right]$, and 25,26-dihydroxyvitamin $\mathrm{D}\left[25,26(\mathrm{OH})_{2} \mathrm{D}\right]$ - as well as vitamin $\mathrm{D}$ binding protein (DBP) were determined simultaneously in mothers and their children from delivery to several months of age. Maternal blood samples, drawn approximately $6 \mathrm{wk}$ before the expected date of delivery, were also analyzed. At delivery, total vitamin $D$ metabolites in maternal and fetal plasma were closely correlated, maternal levels being higher. Unbound (free) vitamin D metabolite concentrations were higher in fetal than in maternal plasma, with the exception of free $1,25(\mathrm{OH})_{2} \mathrm{D}$ levels, which were equal. This suggests a rapid placental transfer of $1,25(\mathrm{OH})_{2} \mathrm{D}$. $24,25(\mathrm{OH})_{2} \mathrm{D}$ and $25,26(\mathrm{OH})_{2} \mathrm{D}$ levels both in mothers and children were closely correlated with the precursor sterol $25 \mathrm{OHD}$. For $1,25(\mathrm{OH})_{2} \mathrm{D}$, no correlation could be demonstrated with any of the other vitamin $D$ metabolites. DBP concentrations in maternal plasma at the time of delivery were about twice the mean adult reference value. In cord blood, DBP levels were in the lower part of the adult reference range. Maternal total $1,25(\mathrm{OH})_{2} \mathrm{D}$ levels, which were twice the reference mean during pregnancy, fell sharply after delivery but free $1,25(\mathrm{OH})_{2} \mathrm{D}$ levels much less. Analogous to the biochemical changes in the mother, the infants' DBP levels fell after birth, as a result of the sudden disappearance of the estrogen stimulus. At the same time, the mineral supply via the placenta was cut off. These two factors are probably responsible for a stimulus to $1,25(\mathrm{OH})_{2} \mathrm{D}$ synthesis (and/ or inhibition of $1,25(\mathrm{OH})_{2} \mathrm{D}$ degradation), resulting in a sharp increase of $1,25(\mathrm{OH})_{2} \mathrm{D}$ and an even stronger increase of free $1,25(\mathrm{OH})_{2} \mathrm{D}$. Concentrations of $25 \mathrm{OHD}$ and $1,25(\mathrm{OH})_{2} \mathrm{D}$ in breast milk were low. Such water-soluble metabolites as 25OHD-glucuronides were not detected. Judged by plasma $250 H D$ levels, the vitamin D stores of most children born to mothers with normal vitamin $D$ status are depleted approximately 8 wk after delivery. Therefore, supplementation with an appropriate dose of vitamin $D$ shortly after birth seems advisable, especially in winter. (Pediatr Res 25: 623-628, 1989)
\end{abstract}

Received July 5, 1988; accepted February 9, 1989.

Correspondence H. J. Degenhart, Department of Paediatrics, Erasmus University and University Hospital, Sophia Children's Hospital, Gordelweg 160, 3038 GE Rotterdam, The Netherlands.

\section{Abbreviations}

25OHD, 25-hydroxycholecalciferol = 25-hydroxyvitamin D

$24,25(\mathrm{OH})_{2} \mathrm{D}, 24,25$-dihydroxyvitamin $\mathrm{D}$

$25,26(\mathrm{OH})_{2} \mathrm{D}, 25,26$-dihydroxyvitamin $\mathrm{D}$

$1,25(\mathrm{OH})_{2} \mathrm{D}, 1,25$-dihydroxyvitamin $\mathrm{D}$

DBP, vitamin $\mathrm{D}$ binding protein

Calcium metabolism in the pregnant woman and the fetus differs extensively from the usual adult pattern. Calcification of the fetal skeleton begins at the 8th wk. At birth, the neonate has accumulated about $30 \mathrm{~g}$ of calcium and $17 \mathrm{~g}$ of phosphorus (1). The maternal skeleton is protected against excessive bone resorption by high calcitonin levels (2). During pregnancy, the fetus builds up vitamin $\mathrm{D}$ stores. This is only possible if vitamin $\mathrm{D}$ and/or its metabolites are able to cross the placenta. As newborn infants are usually not exposed to direct sunlight, they have to rely on these stores.

The aims of this study were 1 ) to obtain information about placental transfer of vitamin $\mathrm{D}$ metabolites by measuring them in maternal and cord plasma at birth; 2) to estimate vitamin D stores in the newborn (indirectly) by longitudinal measurements of the four common vitamin D metabolites in plasma of exclusively breastfed babies; 3) to investigate, by milk analyses, if human milk supplements these stores in exclusively breastfed infants.

\section{MATERIALS AND METHODS}

Subjects. The subjects were 39 pregnant, healthy Caucasian women in the 3rd trimester of pregnancy, who gave their informed consent to participate in this study. All children were born at term, most of them early in October, and were exclusively breastfed. Venous blood samples were drawn simultaneously from mother and infant at birth and after 1, 2, 3, 4, 8, 13, and 21 wk. The number of mother-child pairs was as follows: At birth, 39; 1st wk, 26; 2nd wk 21; 3rd wk 12; 4th wk, 9; 8th wk. $9 ; 13$ th wk, 5; 21st wk, 5. In addition, maternal blood samples were drawn approximately $6 \mathrm{wk}$ before the expected date of delivery.

The four common vitamin D metabolites (see Table 1) and DBP were determined in all samples. After the 1st wk of life, matching breast milk samples were also obtained and kept at $-20^{\circ} \mathrm{C}$ until assayed. There was no clinical evidence of osteo- 
Table 1. Plasma values on day of birth

\begin{tabular}{|c|c|c|c|c|}
\hline \multirow[b]{2}{*}{ Compound } & \multirow[b]{2}{*}{ Unit } & \multicolumn{2}{|c|}{ Fetomaternal difference* } & \multirow[b]{2}{*}{$p$} \\
\hline & & Maternal & Cord & \\
\hline $25 \mathrm{OHD}$ & nmol/liter & $84 \pm 6(39)$ & $55 \pm 4(38)$ & $<0.001$ \\
\hline $24,25(\mathrm{OH})_{2} \mathrm{D}$ & $\mathrm{nmol} / \mathrm{liter}$ & $2.7 \pm 0.3(39)$ & $1.7 \pm 0.2(38)$ & $<0.01$ \\
\hline $25,26(\mathrm{OH})_{2} \mathrm{D}$ & nmol/liter & $1.3 \pm 0.1(39)$ & $0.7 \pm 0.05(38)$ & $<0.001$ \\
\hline $1,25(\mathrm{OH})_{2} \mathrm{D}$ & $\mathrm{pmol} / \mathrm{liter}$ & $155 \pm 10(39)$ & $69 \pm 7(38)$ & $<0.001$ \\
\hline $\mathrm{DBP}$ & $\mathrm{mg} /$ liter & $620 \pm 13(32)$ & $284 \pm 11(31)$ & $<0.001$ \\
\hline $25 \mathrm{OHD}$ free & $\mathrm{pmol} / \mathrm{liter}$ & $1.8 \pm 0.15(31)$ & $2.7 \pm 0.2(31)$ & $<0.001$ \\
\hline $24,25(\mathrm{OH})_{2} \mathrm{D}$ index & $\mathrm{mol} / \mathrm{mol} \cdot 10^{4}$ & $1.8 \pm 0.2(31)$ & $2.4 \pm 0.3(31)$ & $<0.05$ \\
\hline $25,26(\mathrm{OH})_{2} \mathrm{D}$ index & $\mathrm{mol} / \mathrm{mol} \cdot 10^{4}$ & $0.82 \pm 0.07(31)$ & $1.0 \pm 0.08(31)$ & NS \\
\hline $1,25(\mathrm{OH})_{2} \mathrm{D}$ index & $\mathrm{mol} / \mathrm{mol} \cdot 10^{5}$ & $1.1 \pm 0.07(31)$ & $1.1 \pm 0.11(31)$ & NS \\
\hline
\end{tabular}

* Values are mean $\pm \operatorname{SEM}(n)$.

malacia or rickets in any of the mothers or their children, although after the 1st mo several children had elevated alkaline phosphatase levels and/or decreased 25OHD concentrations. All children showed normal growth.

Materials. Sephadex LH-20 was obtained from Pharmacia Fine Chemicals (Woerden, The Netherlands). 25OHD was a gift from Philips Duphar (Weesp, The Netherlands). 1,2(OH $)_{2} \mathrm{D}$, $24,25(\mathrm{OH})_{2} \mathrm{D}$ and $25,26(\mathrm{OH})_{2} \mathrm{D}$ were gifts from Hoffmann-La Roche (Mÿdrecht, The Netherlands). ${ }^{3} \mathrm{H}$-labeled vitamin $\mathrm{D}$ metabolites were purchased from Amersham Corp. (Houten, The Netherlands). HPLC was performed using $\mu$-Porasil and $\mu$-Bondapak C18 columns in a Millipore-Waters system (Etten-Leur, The Netherlands).

Methods. Vitamin $D$ metabolites in plasma. Plasma samples of $2 \mathrm{~mL}$ were extracted twice with $5 \mathrm{~mL}$ diethyl ether and once with $5 \mathrm{~mL}$ dichloromethane. The combined extracts were dried under nitrogen and purified on a $15-\times 0.8-\mathrm{cm}$ Sephadex LH-20 column eluted with hexane: chloroform:methanol $(9: 1: 1$; vol/ vol). The fraction containing 25OHD was further purified by HPLC on a $\mu$-Porasil column (isopropanol:hexane $=2: 98$; vol/ vol). Purification of $25 \mathrm{OHD}$ was achieved by reversed phase HPLC, using a $\mu$-Bondapak $\mathrm{C} 18$ column eluted with water:methanol $(15: 85 ; \mathrm{vol} / \mathrm{vol})$.

Quantification was done with a UV-detector $(254 \mathrm{~nm})$. This method has intra- and interassay variations of 6 and $9 \%$, respectively. The fraction containing the dihydroxylated vitamin $\mathrm{D}$ metabolites was purified on a silica $\mu$-Porasil column eluted with isopropanol:hexane (7:93). Quantification of $24,25(\mathrm{OH})_{2} \mathrm{D}$ and $25,26(\mathrm{OH})_{2} \mathrm{D}$ was performed by a ligand binding assay (3) using human plasma as a source of binding protein. After $24 \mathrm{~h}$ of incubation, phase separation was carried out with dextran-coated charcoal. Quantification of $1,25(\mathrm{OH})_{2} \mathrm{D}$ was done with a radioreceptor assay using the duodenal receptor from rachitic chickens (4).

For $24,25(\mathrm{OH})_{2} \mathrm{D}$ and $25,26(\mathrm{OH})_{2} \mathrm{D}$ the sensitivity of the assay was $12 \mathrm{pg} /$ tube; for $1,25(\mathrm{OH})_{2} \mathrm{D} 2 \mathrm{pg} /$ tube. The intra- and interassay coefficients of variation were 10 and $18 \%$ for $24,25(\mathrm{OH})_{2} \mathrm{D} ; 9$ and $15 \%$ for $25,26(\mathrm{OH})_{2} \mathrm{D} ; 11$ and $15 \%$ for $1,25(\mathrm{OH})_{2} \mathrm{D}$. All samples were corrected for recovery by means of tracers, added before extraction.

$D B P$ and free vitamin $D$ metabolites. Calculation of free vitamin $\mathrm{D}$ metabolite levels requires a total vitamin $\mathrm{D}$ (metabolite) assay and a DBP assay. The latter assay was performed according to Bouillon et al. (5). Measured and calculated free levels agree well if DBP values are not extremely low (6). For the calculation of free $25 \mathrm{OHD}$, we used the numerical value of the $\mathrm{k}_{\mathrm{d}}$ calculated by Bouillon et al. (7). If the exact $\mathrm{k}_{\mathrm{d}}$ value was not known, the $\mathrm{k}_{\mathrm{d}}$ was taken as unity, and free vitamin $\mathrm{D}$ metabolite concentrations were then expressed as the so-called free index, defined as the molar ratio of vitamin D metabolite and DBP.

Vitamin D metabolites in human breast milk. Human breast milk $(10-15 \mathrm{~mL})$ was brought to $\mathrm{pH} 8$ with $0.1-\mathrm{N} \mathrm{KOH}$ and extracted twice with $30 \mathrm{~mL}$ diethyl ether and once with $30 \mathrm{~mL}$ dichloromethane. After every extraction, phases were allowed to separate at $-20^{\circ} \mathrm{C}$. The organic phases were pooled and dried under nitrogen. Sephadex LH-20 chromatography was performed as described above. For further (HPLC) purification of the $25 \mathrm{OHD}$ fraction, a $\mu$-Porasil column was used, eluted with isopropanol:hexane $(99: 1 ; \mathrm{vol} / \mathrm{vol})$. After every four samples, the column was stripped and re-equilibrated. Quantification of $25 \mathrm{OHD}$ was performed by a ligand binding assay as described for $24,25(\mathrm{OH})_{2} \mathrm{D}$ and $25,26(\mathrm{OH})_{2} \mathrm{D}$ measurement in plasma. The assay had a sensitivity of $12 \mathrm{pg} /$ tube. The intra- and interassay coefficients of variation were $16 \%$ and $22 \%$.

Vitamin D-25-glucosiduronate assay. Breast milk $(20 \mathrm{~mL})$ was brought to $\mathrm{pH} 5$ with a concentrated acetate buffer. The final concentration was $0.1-\mathrm{M}$ sodium acetate. Glucuronidase (5000 U) was added (Glucurase; Sigma Chemical Co., St. Louis, MO), and the samples were incubated at $37^{\circ} \mathrm{C}$ overnight, after which they were processed as described for human breast milk. In human breast milk spiked with vitamin D-25-glucosiduronate synthesized according to Nagubandi et al. (8), the recovery was $48 \%$ (measured as 25OHD).

\section{STATISTICS}

Student's $t$ test and linear regression analysis were used as appropriate. The calculation of reference ranges for the vitamin D metabolites was performed as follows. Blood samples were drawn from 36 volunteers at random moments throughout the year. This relatively small set of "normal values" was used for the calculation of percentiles using a bootstrap technique described below (9).

From the original set of "normal values," entries were drawn at random to construct a new set of "normal values." At every random "draw," each concentration has an equal chance of being selected. After 99 "draws," the new set is complete. Some of the original values will occur several times; others will have escaped the drawing process. The new set allows the definition of the 90 th, 80 th, etc. percentile. This process was repeated $10^{4}$ times, resulting in $10^{4}$ values for each percentile. The resulting mean of each percentile was considered to be an adequate approximation of the "real" percentile. It was found that the final distributions very closely resembled log-normal distributions.

\section{RESULTS}

Plasma. The results obtained for total and free vitamin D metabolites and DBP are shown in Figures 1 and 2. No significant differences (Student's $t$ test) were observed for any of the biochemical parameters on the $\mathrm{d}$ of birth between the mother-infant pairs who withdrew before the $21 \mathrm{st}$ wk and the five pairs who stayed in this study until its conclusion.

Table 1 presents a compilation of the data obtained from the analysis of maternal and cord plasma. On the $\mathrm{d}$ of birth, maternal plasma levels for $25 \mathrm{OHD}, 24,25(\mathrm{OH})_{2} \mathrm{D}, 25,26(\mathrm{OH})_{2} \mathrm{D}$, $1,25(\mathrm{OH})_{2} \mathrm{D}$, and DBP exceeded cord levels. Free $25 \mathrm{OHD}$ and 

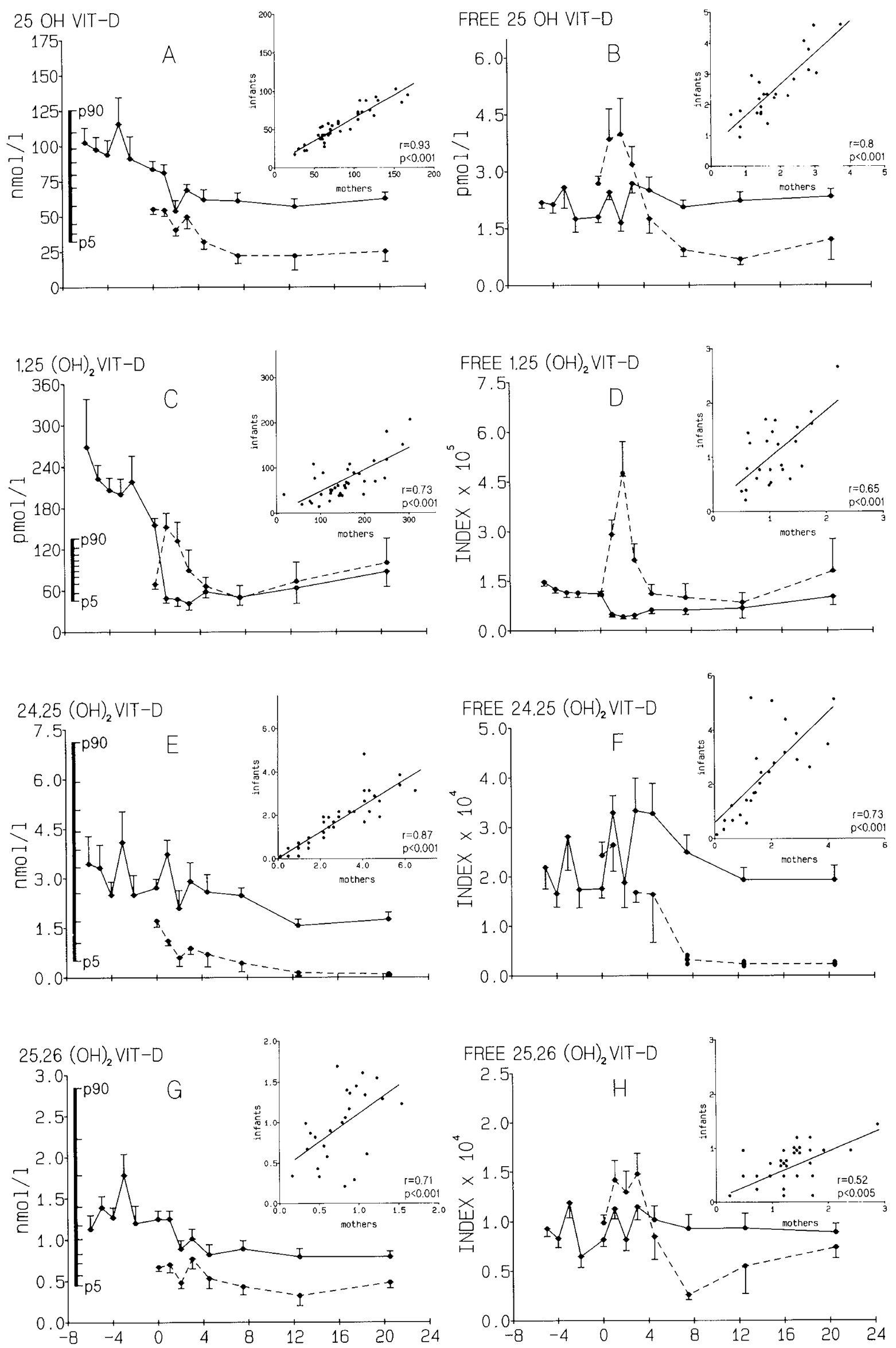

Fig. 1. Total and free vitamin D metabolite concentrations, mean \pm SEM, in plasma of mothers $(\bullet-\bullet)$ and children $(\bullet-.-\bullet)$ vs. time in wk $(0$ $=\mathrm{d}$ of delivery). Insets represent the correlation between mothers and infants, at $\mathrm{d}$ of birth only. Vertical bars: reference ranges expressed as percentiles, p5, p10, p20, p30, p40, p50, p60, p70, p80, and p90 are indicated. 
the $24,25(\mathrm{OH})_{2} \mathrm{D}$ index were higher in cord than in maternal plasma. The $25,26(\mathrm{OH})_{2} \mathrm{D}$ and $1,25(\mathrm{OH})_{2} \mathrm{D}$ indices were not significantly different in maternal and infant plasma.

On the $\mathrm{d}$ of birth, a positive fetomaternal correlation existed for both total and free vitamin D metabolites (insets in Fig. 1). In the case of the $1,25(\mathrm{OH})_{2} \mathrm{D}$ index, the slope of the regression line did not differ significantly from 1, indicating an almost perfect $1: 1$ relationship. DBP levels in maternal and cord plasma were not significantly correlated. In the mother during pregnancy, $25 \mathrm{OHD}, 24,25(\mathrm{OH})_{2} \mathrm{D}$ and $25,26(\mathrm{OH})_{2} \mathrm{D}$ were all significantly $(p<0.001)$ intercorrelated. On the day of birth, $25 \mathrm{OHD}$ was positively correlated with $24,25(\mathrm{OH})_{2} \mathrm{D}$ and with $25,26(\mathrm{OH})_{2} \mathrm{D}(p<0.001)$ in both mothers and children. $24,25(\mathrm{OH})_{2} \mathrm{D}$ and $25,26(\mathrm{OH})_{2} \mathrm{D}$ were correlated at the $p<0.01$ level (also in both mothers and in children).

At 1 wk postpartum, $25 \mathrm{OHD}$ and $24,25(\mathrm{OH})_{2} \mathrm{D}$ were still correlated at the $p<0.001$ level (mothers and children), but the significance level of the correlation between 25OHD and $25,26(\mathrm{OH})_{2} \mathrm{D}$ in the mothers had dropped to $p<0.01$. In the children, the correlation disappeared. The correlation between $24,25(\mathrm{OH})_{2} \mathrm{D}$ and $25,26(\mathrm{OH})_{2} \mathrm{D}$ had disappeared in the children, and in the mother not more than the $p<0.05$ level was reached.

After the $3 \mathrm{rd}$ wk, no correlation between 25OHD and $24,25(\mathrm{OH})_{2} \mathrm{D}$ could be demonstrated. As early as 1 wk after birth, no correlation could be demonstrated between $25,26(\mathrm{OH})_{2} \mathrm{D}$ levels and its precursor $25 \mathrm{OHD}$. For $1,25(\mathrm{OH})_{2} \mathrm{D}$, no correlation could be demonstrated with any of the other vitamin $\mathrm{D}$ metabolites, neither before delivery (mothers), or thereafter (mothers and children).

Breast milk. Levels of (unconjugated) 25OHD in breast milk are given in Figure 3. In milk, a mean value of $325 \mathrm{pmol} / \mathrm{mL}$ was found, $0.4 \%$ of the maternal plasma value. Milk and maternal plasma values were positively correlated $(p<0.05$ or better) up to $5 \mathrm{wk}$ after delivery. Figure 4 demonstrates the good correlation between maternal plasma and milk values of $25 \mathrm{OHD}$ in the 1 st wk after birth. Only trace amounts of unconjugated

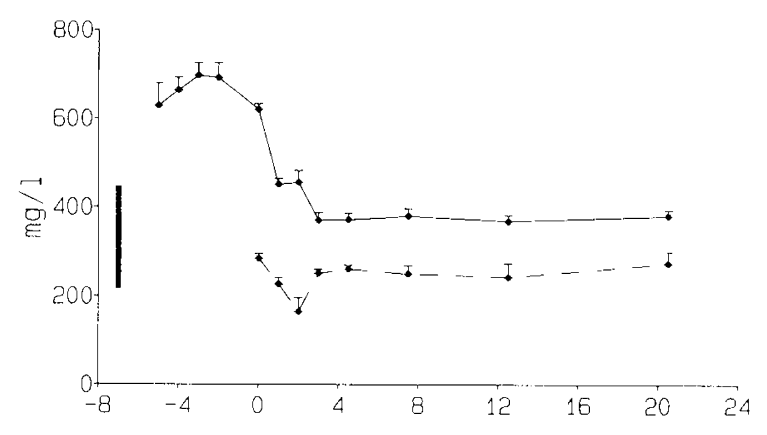

Fig. 2. Vitamin $D$ binding protein, mean \pm SEM, in plasma of mothers $(\bullet-\bullet)$ and children $(\bullet--\bullet)$ vs. time in wk $(0=\mathrm{d}$ of delivery). Vertical bar: reference range, mean $\pm 2 \mathrm{SD}$.

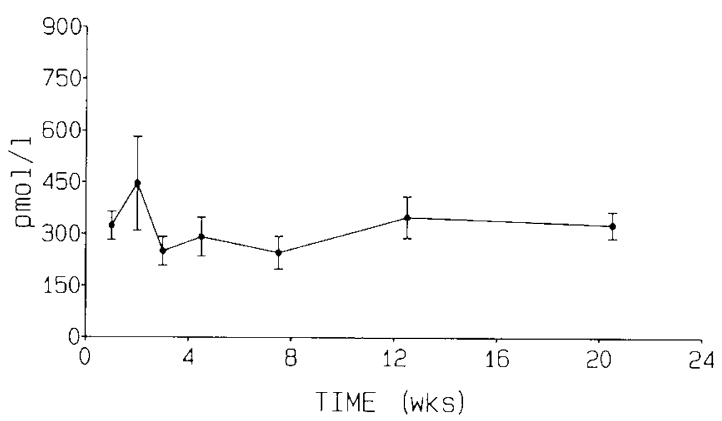

Fig. 3. 25-hydroxyvitamin $\mathrm{D}$ in breast milk, mean $\pm \mathrm{SEM}$, vs. time in wk.

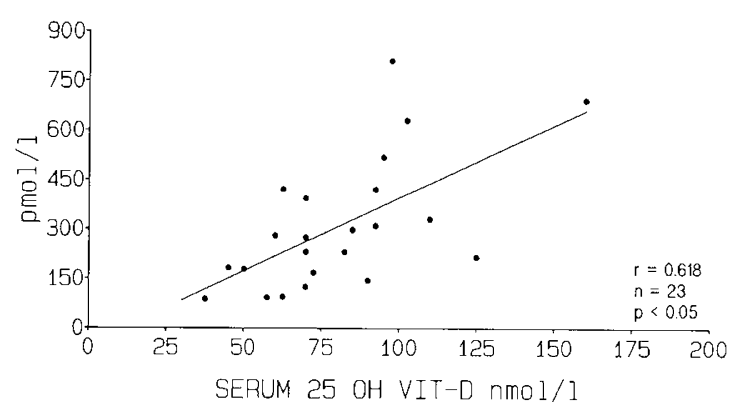

Fig. 4. Correlation between maternal plasma and breast milk concentrations of 25-hydroxyvitamin D, 1 wk after delivery.

$1,25(\mathrm{OH})_{2} \mathrm{D}$ could be detected (mean value, $\sim 24 \mathrm{pmol} / \mathrm{mL}$ ). In breast milk subjected to enzymatic hydrolysis by means of glucuronidase, the presence of glucuronides of $25 \mathrm{OHD}$ and $1,25(\mathrm{OH})_{2} \mathrm{D}$ could not be detected.

\section{DISCUSSION}

Vitamin D metabolites in plasma. The group of mothers we studied delivered at the end of summer. High plasma 25OHD levels in the mothers were therefore expected. Maternal plasma values of $25 \mathrm{OHD}, 24,25(\mathrm{OH})_{2} \mathrm{D}$ and $25,26(\mathrm{OH})_{2} \mathrm{D}$ before delivery were within the adult reference range, whereas $1,25(\mathrm{OH})_{2} \mathrm{D}$ levels were about twice the normal mean. This is in agreement with data in the literature. During pregnancy, unaltered or slightly decreased values were reported for $25 \mathrm{OHD}(10,11)$ and for $24,25(\mathrm{OH})_{2} \mathrm{D}(12)$. High maternal $1,25(\mathrm{OH})_{2} \mathrm{D}$ values during pregnancy and at term are well documented (10-12). At birth the four vitamin $D$ metabolites were significantly lower in cord than in maternal plasma. In contrast with total vitamin $D$ metabolite concentrations, free $25 \mathrm{OHD}, 24,25(\mathrm{OH})_{2} \mathrm{D}$, and $25,26(\mathrm{OH})_{2} \mathrm{D}$ levels were higher in cord than in maternal plasmas, but free $1,25(\mathrm{OH})_{2} \mathrm{D}$ levels were virtually identical in maternal and cord plasma. Maternal DBP plasma levels, which are mainly under estrogen control, decrease sharply after birth. Free maternal $1,25(\mathrm{OH})_{2} \mathrm{D}$ levels were halved within $1 \mathrm{wk}$.

In our study, maternal postpartum $24,25(\mathrm{OH})_{2} \mathrm{D}$ and $25,26(\mathrm{OH})_{2} \mathrm{D}$ levels followed the $25 \mathrm{OHD}$ pattern, which, taking into account the mean date of delivery, is in good agreement with seasonal variations as described for The Netherlands (13). Total $1,25(\mathrm{OH})_{2} \mathrm{D}$ in infants rose sharply shortly after birth. Decreasing DBP levels in the $2 \mathrm{nd}$ wk led to a 5 -fold increase in free $1,25(\mathrm{OH})_{2} \mathrm{D}$. High $1,25(\mathrm{OH})_{2} \mathrm{D}$ levels reported on the 4 th $\mathrm{d}$ of life (14) are in good agreement with our observation of a sharp rise of $1,25(\mathrm{OH})_{2} \mathrm{D}$ after the 1 st wk. One study reported an increase as early as $24 \mathrm{~h}$ after delivery (15). This increase of $1,25(\mathrm{OH})_{2} \mathrm{D}$ and the even stronger increase of free $1,25(\mathrm{OH})_{2} \mathrm{D}$ may be a physiologic response to the cut-off in the mineral supply via the placenta.

Towards the end of the study, plasma $24,25(\mathrm{OH})_{2} \mathrm{D}$ levels decreased rapidly, reaching almost undetectable levels, whereas the correlation with $25 \mathrm{OHD}$ disappeared after the $3 \mathrm{rd}$ wk. The biochemical function of $24,25(\mathrm{OH})_{2} \mathrm{D}$ in early childhood (if any) remains obscure. It might, however, be used as an "indicator" of the vitamin $\mathrm{D}$ stores (see below). Free $25,26(\mathrm{OH})_{2} \mathrm{D}$ levels may be involved in maintaining the fetomaternal calcium gradient. Using multiple linear regression analysis, up to $40 \%$ of this gradient could be explained by fetal PTH levels and the difference between fetal and maternal free $25,26(\mathrm{OH})_{2} \mathrm{D}$ (manuscript in preparation). The levels of $25,26(\mathrm{OH})_{2} \mathrm{D}$ at birth were tightly correlated witth the substrate $250 \mathrm{OHD}$. After birth, the levels remained relatively constant, but the correlation with $25 \mathrm{OHD}$ levels disappeared. Compared to adults, in whom $25,26(\mathrm{OH})_{2} \mathrm{D}$ synthesis seems to be dependent upon the availability of the 
precursor $25 \mathrm{OHD}$, the situation in neonates becomes distinctly different after the 1 st weeks of life.

Placental transport. The most remarkable finding is that free $1,25(\mathrm{OH})_{2} \mathrm{D}$ concentration in mothers equals the concentration observed in children. Experiments have demonstrated the transport of vitamin $\mathrm{D}$ (metabolites) from mother to fetus (16). Net placental transport was more rapid for 25OHD than for vitamin $\mathrm{D}$ in ewes (17) and more rapid for $1,25(\mathrm{OH})_{2} \mathrm{D}$ than for $25 \mathrm{OHD}$ in human placentas (18). In a pregnant vitamin $\mathrm{D}$ receptor deficient patient, receiving very high doses of $1,25(\mathrm{OH})_{2} \mathrm{D}$, maternal and cord levels of total $1,25(\mathrm{OH})_{2} \mathrm{D}$ were found to be high and identical (19).

It seems reasonable that analogous transport mechanisms (active transport or passive diffusion) are involved for all four vitamin $\mathrm{D}$ metabolites. One could speculate that only free metabolites can cross the placenta and that free $1,25(\mathrm{OH})_{2} \mathrm{D}$ determines the set point for the DBP level in the fetus. The fact that levels of free $25 \mathrm{OHD}$, free $24,25(\mathrm{OH})_{2} \mathrm{D}$, and free $25,26(\mathrm{OH})_{2} \mathrm{D}$ are higher in cord than in maternal plasma is compatible with active transport against a gradient for these metabolites.

Vitamin D metabolites in milk. Total antirachitic activity in milk of nonvitamin D-supplemented lactating mothers is low $(15-50 \mathrm{U} /$ liter $)(20,21)$ and vitamin $\mathrm{D}$ sulfate levels were undetectable (22). Besides being sulfated, steroids and sterols are also often excreted conjugated with glucuronic acid. Although water-soluble vitamin $\mathrm{D}$ glucuronides were indeed reported to occur in the bile of rats (23) and of chickens (24), we have demonstrated that these metabolites do not contribute to the antirachitic activity in human breastmilk.

In milk, we found a mean 25OHD level of $325 \mathrm{pmol} / \mathrm{liter}$ This is in good agreement with previous data $(21,25)$. Reported levels depend upon methodology, geographic site, ethnic origin, and food fortification. Values of $1,25(\mathrm{OH})_{2} \mathrm{D}$ milk in our study were $3.4 \mathrm{pmol} /$ liter. This is also in agreement with literature values $(20,21)$. Our data confirm a positive correlation between levels of $25 \mathrm{OHD}$ in maternal plasma and breast milk (Fig. 4), as found by Hollis et al. (25). A relationship between vitamin D intake and 25OHD levels in breast milk was found by Specker et al. (26).

Calcium absorption mechanisms in the newborn. Intestinal calcium absorption in the newborn is not solely under control of $1,25(\mathrm{OH})_{2} \mathrm{D}$. Alkaline phosphatase for example can act as a calcium transporting protein (27). Lactose, amply available in breast milk, also may facilitate intestinal calcium absorption in the newborn. We think $1,25(\mathrm{OH})_{2} \mathrm{D}$ has a function in early childhood. At birth, maternal and fetal free $1,25(\mathrm{OH})_{2} \mathrm{D}$ levels are accurately attuned to each other, probably for the determination of the setpoint for DBP levels in the fetus. After birth, the infant's $1,25(\mathrm{OH})_{2} \mathrm{D}$ rises sharply, which can be explained as a stimulus for the intestine to absorb calcium. Furthermore, hypocalcemic newborns respond to $1,25(\mathrm{OH})_{2} \mathrm{D}$ therapy. However, the fact that only high-dose therapy is effective is circumstantial evidence that calcium absorption is not under $1,25(\mathrm{OH})_{2} \mathrm{D}$ control only. Last but not least, strong evidence for $1,25(\mathrm{OH})_{2} \mathrm{D}$ independent mechanisms is provided by two conditions in which $1,25(\mathrm{OH})_{2} \mathrm{D}$ cannot exert its function: $1 \alpha$-hydroxylase deficiency and $1,25(\mathrm{OH})_{2} \mathrm{D}$ receptor deficiency. Affected patients manage to tide over a period of at least 6 mo until the first clinical signs occur $(28,29)$. The existence of $1,25(\mathrm{OH})_{2} \mathrm{D}$ independent calcium absorption mechanisms may explain the lack of correlation between $1,25(\mathrm{OH})_{2} \mathrm{D}$ and other clinical chemical parameters in early childhood. With aging the active $\left(1,25(\mathrm{OH})_{2} \mathrm{D}\right.$ dependent $)$ processes seem to become more important (30).

Vitamin D supplementation. With regard to seasonal influences, the timing of this study was optimal. Mothers delivered at the end of the summer and had the full benefit of effective solar radiation resulting in high $25 \mathrm{OHD}$ plasma levels. However, in the children after the 1 st mo some warning signs of vitamin D depletion became detectable. After one month 25OHD levels in some children were later found to have reached undesirably low levels and around the 8th wk $70 \%$ of the children had plasma $25 \mathrm{OHD}$ levels below the 5 th adult reference percentile. Indeed, exclusively breast-fed infants showed a gradual reduction of bone mineral content up to the 12th wk of life when compared with infants receiving breast milk plus vitamin $\mathrm{D}$ supplementation or formula feeding (31). Assuming $24,25(\mathrm{OH})_{2} \mathrm{D}$ is an inactive metabolite of $25 \mathrm{OHD}$, the low vanishing levels of the former might be additional evidence for the depletion of vitamin $\mathrm{D}$ stores, favoring the biosynthesis of the active metabolite $1,25(\mathrm{OH})_{2} \mathrm{D}$.

At approximately $8 \mathrm{wk}$, in $50 \%$ of the children, a moderately elevated phosphatase level was also observed (mean value of the "high phosphatase group" was $610 \mathrm{U} /$ liter; upper reference value $500 \mathrm{U} /$ liter).

In most European countries, breast feeding is common. In the Scandinavian countries, over $50 \%$ of infants at the age of 3 mo are still exclusively breastfed; the overall percentage for Europe exceeds $20 \%$ (32). In the Netherlands, this figure is about $30 \%$ (33). In the Netherlands, babies are not given vitamin $\mathrm{D}$ before the $3 \mathrm{rd}$ mo of life. The same is probably the case in several other countries. Our findings suggest that vitamin D supplementation, regardless the season of birth, should be started in the 1st or the 2nd wk of life.

Acknowledgments. The authors thank Mrs. Suzan Zwakhals for her friendly help and support during the planning of the experiment and the sample collection, Dr. D. Sainsbury and Mr. P. F. J. Koppens for their critical reading of the manuscript and their valuable suggestions, Dr. R. S. Boeken Krüger-Mangunkusomo (Provinciale Kruisorganisatie Zuid-Holland), and Dr. E. Helsing (WHO, Copenhagen) for supplying us with the data on the incidence of breastfeeding. Ms. K. A. Wielsma and Mr. J. de Kuyper are gratefully acknowledged for their help with the preparation of the manuscript. Finally, we thank the mothers and their children who volunteered in this research project.

\section{REFERENCES}

1. Ziegler EE, O'Donnel AM, Nelson SE, Fomon SJ 1976 Body composition of the reference fetus. Growth 40:329-341

2. Lewis P, Rafferty R, Shelly M 1971 A suggested physiological role for calcitonin: the protection of the skeleton during pregnancy and lactation. $J$ Endocrinol 49:ix-x

3. Belsey R, DeLuca HF, Potts $\mathrm{T} 1971$ Competitive binding assay for vitamin D and 25OH-vitamin D. J Clin Endocrinol Metab 33:554-557

4. Eisman JA, Hamstra AJ, Kream BE, DeLuca HF 1976 1,25-Dihydroxyvitamin D in biological fluids: a simplified and sensitive assay. Science 193:10211023

5. Bouillon R, Van Baelen H, De Moor $P 1977$ The measurement of the vitamin D-binding protein in human serum. J Clin Endocrinol Metab 45:225-228

6. Bikle DD, Siiteri DK, Ryzen E, Haddad JG, Gee E 1985 Serum protein binding of 1,25-dihydroxyvitamin $\mathrm{D}$ : a reevaluation by direct measurement of free metabolite levels. J Clin Endocrinol Metab 61:969-975

7. Bouillon R, Van Kerkhove P, De Moor P 1976 Characteristics of the vitamin $D$ binding protein in different species. Calcif Tissue Res 21:172-176

8. Nagubandi S, Kumar R, Londowski JM, Corradino RA, Tietz PS 1980 Role of vitamin D glucosiduronate in calcium homeostasis. J Clin Invest 66:12741280

9. Diaconis P, Efron B 1983 Computer-intensive methods in statistics. Sci Am 248:96-108

10. Bouillon R, Van Assche FA, Van Baelen H, Heyns W, De Moor P 1981 Influence of the vitamin D-binding protein on the serum concentration of 1,25-di-hydroxyvitamin D3. Significance of the free 1,25-dihydroxyvitamin D3 concentration. J Clin Invest 67:589-596

11. Reddy SG, Norman AW, Willis DM, Goltzman D, Guyda H, Solomon S Philips DR, Bishop JE, Mayer E 1983 Regulation of vitamin D metabolism in normal human pregnancy. J Clin Endocrinol Metab 56:363-370

12. Wieland P, Fischer JA, Trechsel U, Roth HR, Vetter K, Schneider H, Huch A 1980 Perinatal parathyroid hormone, vitamin D metabolites, and calcitonin in man. Am J Physiol 239:E385-E390

13. Juttman JR, Visser TJ, Buurman C, De Kam E, Birkenhäger JC 1981 Seasonal fluctuations of vitamin $\mathrm{D}$ metabolite concentrations in serum of normal subjects. Br Med J 282:1349-1352

14. Markestad $T 1983$ Plasma concentrations of vitamin $D$ metabolites in unsupplemented breast-fed infants. Eur J Pediatr 141:77-80

15. Steichen JJ, Tsang RC, Gratton TL, Hamstra A, DeLuca HF 1980 Vitamin D homeostasis in the perinatal period. 1,25-Dihydroxyvitamin $\mathrm{D}$ in maternal, cord and neonatal blood. N Engl J Med 302:315-319

16. Schedewie H, Slikker W, Hill D, Tsang R, Bailey J, Elders J 1980 Placental crossover and fetal tissue distribution of $1,25(\mathrm{OH})_{2}$ vitamin $\mathrm{D}$ in rhesus monkey. Pediatr Res 14:580 (abstr)

17. Hidiroglou M, Williams CJ 1981 Transfer of tritium-labeled vitamin D3 and 25-hydroxyvitamin D3 in ovine placenta. Am J Vet Res 42:140-141 
18. Ron M, Levitz M, Chuba J, Dancis J 1984 Transfer of 25-hydroxyvitamin D3, and 1,25-dihydroxyvitamin D3 across the perfused human placenta. Am J Obstet Gynecol 148:370-374

19. Marx SJ, Swart EG, Hamstra AJ, DeLuca HF 1980 Normal intrauterine development of the fetus of a woman receiving extraordinarily high doses of 1,25-dihydroxyvitamin D3. J Clin Endocrinol Metab 51:1138-1142

20. Hollis BW, Roos BA, Draper HH, Lambert PW 1981 Vitamin D and its metabolites in human and bovine milk. J Nutr 111:1240-1248

21. Reeve LE, Chesney RW, DeLuca HF 1982 Vitamin D of human milk: identification of biologically active forms. Am J Clin Nutr 36:122-126

22. Greer FR, Reeve LE, Chesney RW, DeLuca HF 1982 Water-soluble vitamin $\mathrm{D}$ in human milk: a myth. Pediatrics $69: 238$

23. Bell PA, Kodicek F 1969 Investigations on metabolites of vitamin-D in rat bile: separation and partial identification of a major metabolite. Biochem $\mathbf{J}$ 115:633-669

24. LeVan LW, Schnoes HK, DeLuca HF 1981 Isolation and identification of 25hydroxyvitamin $D_{2} 25$-glucuronide: a biliary metabolite of vitamin $D_{2}$ in the chick. Biochemistry 20:222-226

25. Hollis BW, Pittard WB, Reinhardt TA 1986 Relationships among vitamin D, 25 -hydroxyvitamin $\mathrm{D}$, and vitamin $\mathrm{D}$-binding protein concentrations in the plasma and milk of human subjects. J Clin Endocrinol Metab 62:41-44 26. Specker BL, Tsang RC, Hollis BW 1985 Effect of race and diet on humanmilk vitamin D and 25-hydroxyvitamin D. Am J Dis Child 139:1134-1137

27. Russel RGG, Monod A, Bonjour JP, Fleisch H 1972 Relation between alkaline phosphatase and Ca-ATPase in calcium transport. Nature 240:126-127

28. Marx SJ, Liberman UA, Eil C, Gamblin GT, DeGrange DA, Balsan S 1984 Hereditary resistance to 1,25-dihydroxyvitamin D. Recent Prog Horm Res 40:589

29. Nelson WE, Behrnun RE, Vaughan VC 1987 Textbook of Pediatrics, 13th edition. WB Saunders Company, Philadelphia

30. Ghisan FK, Parleor P, Nichols S, Hoyumpa A 1984 Kinetics of intestinal calcium transport during maturation in rats. Pediatr Res 18:235-239

31. Greer FR, Searcy JE, Levuin RS, Steichen JJ, Steichen-Asch P, Tsang RC 1981 Bone mineral content and serum 25-hydroxyvitamin $D$ concentrations in breast-fed infants with and without supplemental vitamin D. J Pediatr 98:696-701

32. Infant and young child nutrition in Europe 1985 (ICP/NUT 110 1402V). World Health Organization. Regional office for Europe, Copenhagen

33. Annual report Youth Health Care 0-4 year: National Bureau for Infant Welfare. Data obtained from RS Boeken Krüger-Mangunkusumo 